\title{
IMMUNOLOGICAL CROSS-REACTION OF BOVINE GROWTH HORMONE (NIH-GH-B8) WITH THE ANTISERUM TO THE BOVINE DIABETOGENIC PROTEIN*
}

\author{
GeNE F. TUTWILER $\dagger$ \\ Department of Biological Chemistry, University of Michigan, Ann Arbor, Michigan, U.S.A.
}

(Received 18 December 1973)

\begin{abstract}
The immunological cross-reaction of bovine growth hormone (BGH, NIH-GH-D8) with the antiserum to the bovine diabetogenic protein (BDP) has been determined to be the result of contamination of the BGH preparation with a highly anionic protein.

2. This highly anionic protein is probably BDP.
\end{abstract}

\section{INTRODUCTION}

A DIABETOGENIC PROTEIN (DP) has been isolated from bovine (Louis et al., 1965, 1966), ovine, porcine (Louis \& Conn, 1968) and human (Louis \& Conn, 1972) pituitary glands. A similar substance has been isolated from the urine of patients with lipoatrophic diabetes (Louis et al., 1963) and from the urine of diabetes mellitus patients with proteinuria (Louis \& Conn, 1969). The substances from the above sources are capable of inducing hyperglycemia and insulin resistance in men and dogs.

Recently, in a report from this laboratory (Tutwiler, 1975), it was found that the rabbit antiserum (anti-BDP) to the bovine pituitary diabetogenic protein (BDP) reacted with ovine DP, but not with human or porcine DP. Similarly, Hayashida \& Li (1959) demonstrated that an antiserum to bovine growth hormone (BGH) reacted only with ovine $\mathrm{GH}$ but not human, monkey, procine or whale. The similarity of DP and GH species specificities and the previously reported finding that BGH reacts to identity with anti-BDP (Tutwiler, 1975) has prompted this report. The preliminary studies presented here will supply a possible explanation for immunological similarity of BDP and BGH.

\section{MATERIALS AND METHODS}

The methods for preparation of the bovine diabetogenic protein and antiserum have been published elsewhere (Tutwiler, 1975). The bovine growth hormone used was supplied by U.S. National Institutes of Health (NIH-GHB8) and was dissolved in $0.9 \% \mathrm{NaCl}$ with the addition of a small amount of $0.05 \mathrm{~N} \mathrm{NaOH}$. The diabetogenic

* Supported in part by Grant GM00187 from NIH to the Department of Biological Chemistry, University of Michigan.

† Present address: Department of Biochemical Research, McNeil Laboratories, Inc., Camp Hill Road, Fort Washington, Pennsylvania 19034, U.S.A. protein was dissolved by a method described previously (Louis et al., 1963).

Microscopic slides coated with $1 \%$ agarose (Sigma) were used for immunoelectrophoresis. The agar was prepared in barbital buffer, $\mathrm{pH} 8 \cdot 2$, ionic strength $-0 \cdot 1$. Electrophoresis of antigens was for $2 \mathrm{hr}$ in barbital buffer ( $5 \mathrm{mM}$ /plate). Precipitin bands were stained with $0.5 \%$ Amido schwarz in $0.045 \mathrm{~N}$ acetate buffer (10\% glycerine). After electrophoresis of antigens, some plates were stained for location of proteins with triple protein stain $(0.1 \%$ thiazine red R, Amido schwarz 10B, light green SF and mercuric chloride in $2 \%$ acetic acid).

\section{RESULTS AND DISCUSSION}

BGH has previously been observed to react to identity with an antiserum to the bovine diabetogenic protein (anti-BDP) in agar diffusion experiments (Tutwiler, 1974). However, in these studies, BDP was found to be a better antigen than BGH. About 100 times more BGH was needed to manifest a reaction with anti-BDP. The cross-reaction was unexpected and the reasons for it are unclear. BGH and BDP might have a common antigenic determinant. Certainly, if this were the case, the BGH determinant must fit only some of the BDP antibody molecules or it may fit poorly into the antibody combining site. Also, the cross-reaction could be explained if NIH-BGH were contaminated with BDP or if the antiserum had been produced against a BDP preparation contaminated with BGH.

Figure 1 supplies a possible explanation. The figure shows the results of immunoelectrophoresis of the bovine diabetogenic protein and growth hormone which were run simultaneously. It is evident that the main component of NIH bovine growth hormone did not react with the antibody and was clearly different from BDP by its electrophoretic mobility. BGH has an isoelectric point of 6.8 and would therefore be expected to move very little under the conditions used for electrophoresis. 
The results demonstrate that the main component of $\mathrm{BGH}$ moved slightly from the origin toward the cathode. On the other hand, BDP has an isoelectric point of $4 \cdot 1$ and would be expected to move far toward the anode. This was substantiated experimentally. However, of great interest is the observation that a minor component of BGH has moved very far toward the anode and reacted with the antibody. When BDP was spotted together with BGH only one precipitin band formed at the anode. It is probable, therefore, that there is a very negatively charged contaminant (under the conditions used) in this NIH-BGH preparation which is responsible for the cross-reaction with anti-BDP. Because this component of $\mathrm{BGH}$ is electrophoretically similar to BDP under the conditions used and since the precipitin band of BDP and the contaminant are not separable, it is probable that the contaminant may be bovine diabetogenic protein. In the system used a minimum of 1/80-1/100 contamination would certainly be demonstrable.

Further evidence of contamination has been obtained by Dr. L. H. Louis in our laboratory. He has removed a proteinaceous material at the isoelectric point of BDP (pH 4.1) from the same BGH preparations which were used above. After this material was removed, we demonstrated that the material that precipitated at $\mathrm{pH} 6.8$ (isoelectric point of $\mathrm{BGH}$ ) no longer reacted with anti-BDP while the original $\mathrm{BGH}$ preparation did react. Repurification of the $\mathrm{BGH}$ had either removed a contaminant, or the BGH has been damaged.

In addition, it seems unlikely that the crossreaction is a result of the antisera being produced against a BDP preparation which contained BGH contamination. The BDP preparation used was non-growth promoting and the crude protein (purified by Dr. L. H. Louis) had only about onethousandth the affinity for anti-growth hormone as BGH (Tutwiler \& I.ouis, 1971).

Further physiochemical and biological studies are necessary in order to definitely say that the BGH contaminant is BDP. Since BDP has some biological activities which are similar to BGH (Tutwiler, 1970), the potential BDP contamination in NIH-BGH could open for question those biological studies in which pharmacological doses of BGH were used.

\section{REFERENCES}

HaYAShida T. \& Li C. H. (1959) A comparative immunological study of pituitary growth hormone from various species. Endocrinology 65, 944-956.

Louis L. H. \& ConN J. W. (1968) A diabetogenic polypeptide from hog and sheep adenohydropophysis similar to that found in lipoatrophic diabetes. Metabolism 17, 475-484.

LouIs L. H. \& ConN J. W. (1969) A urinary diabetogenic polypeptide in proteinuric diabetic patents. Metabolism 18, 556-563.

Louis L. H. \& ConN J. W. (1972) Diabetogenic polypeptide from human pituitaries similar to that excreted by proteinuric diabetic patients. Metabolism 21, 1-9.

Louis L. H., ConN J. W. \& Minick M. C. (1963) Isolation and characterization of an insulin antagonist from urine. Metabolism 12, 867-886.

Louis L. H., CONN J. W. \& MINICK M. C. (1965) Isolation of a peptide from bovine adnohypophysis which induces hyperglycemia and insulin resistance in men and dogs. Diabetes 14, 445.

Louis L. H., ConN J. W. \& Minick M. C. (1966) A diabetogenic polypeptide from bovine adenolypophysis similar to that excreted in lipoatrophic diabetes. Metabolism 15, 309-324.

Tutwiler G. F. (1970) Physiochemical and biological characterization of a diabetogenic peptide from bovine adenohypophysis. Thesis, University of Michigan.

TUTWILER G. F. (1975) Immunological characterization of a diabetogenic protein from bovine adenohypophysis. Comp. Biochem. Physiol. 50A, 585-687.

Tutwiler G. F. \& Louis C. H. (1971) Glycostatic effect of a diabetogenic non-growth promoting pituitary polypeptide. Int. J. Biochem. 2, 319-323.

Key Word Index-Bovine growth hormone; diabetogenic protein; immunology. 


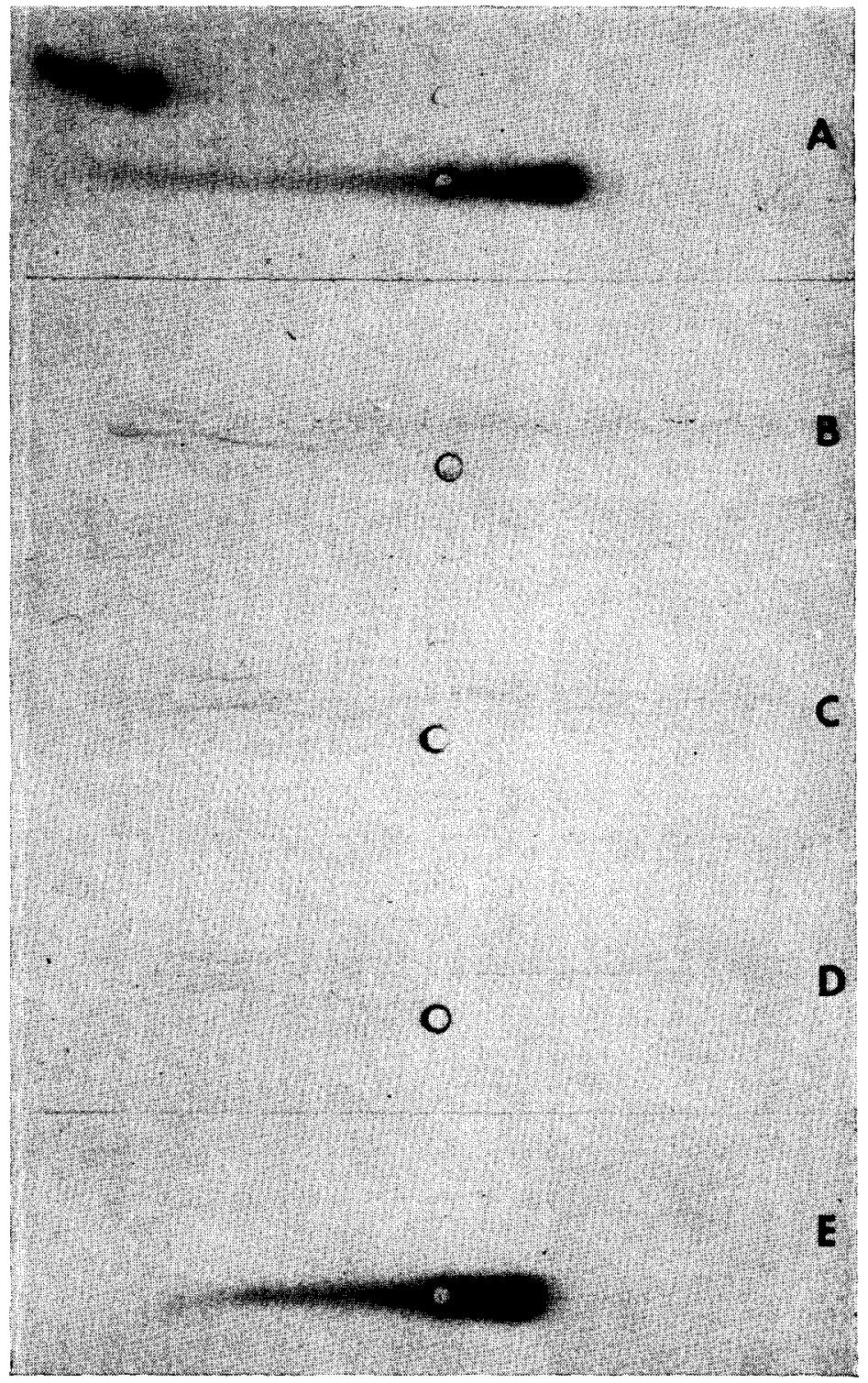

Fig. 1. Immunoelectrophoresis of bovine diabetogenic peptide and growth hormone on agarose. BDP $(100 \mu \mathrm{g} / \mathrm{ml})$ was placed in the top well of plates $\mathrm{B}, \mathrm{C}, \mathrm{D}$ and $\mathrm{E} ; \mathrm{BDP}(3.5 \mathrm{mg} / \mathrm{ml})$ was placed in the top well of plate A; BGH $(12 \mathrm{mg} / \mathrm{ml})$ was placed in lower well of plates $\mathrm{A}, \mathrm{B}, \mathrm{C}, \mathrm{D}$ and E; BDP $(\sim 0.4 \mu \mathrm{g})$ was also added to lower well of plate $C$. Each well was filled with $\sim 2 \mu \mathrm{l}$ of sample. Electrophoresis was for $1 \frac{3}{4} \mathrm{hr}, \mathrm{pH} 8 \cdot 2$. The center wells of plates $\mathrm{B}, \mathrm{C}$ and $\mathrm{D}$ were filled with undiluted antiBDP. Plates $A$ and $E$ were stained with triple protein stain immediately after electrophoresis, while B, C and D were stained with Amido schwarz after precipitin band formation. The anode appears to the left, the cathode to the right. 